\title{
O processo da pesquisa sobre Jesus histórico e o surgimento do Judaísmo Messiânico
}

\section{The process of research on Historical Jesus and the rise of \\ Messianic Judaism}

\author{
Solange Maria do Carmo * \\ Aila Luiza Pinheiro de Andrade **
}

\begin{abstract}
Resumo
A modernidade trouxe um impacto sobre a fé cristã e suas consequências ainda persistem na pósmodernidade. No campo da teologia, a demanda por uma resposta científica às questões da modernidade fez surgir a pesquisa sobre o Jesus histórico. Houve uma necessidade premente de saber quem é Jesus, como viveu, como agia, qual o mundo no qual estava inserido ou quais as palavras ele teria, de fato, pronunciado. Tal pesquisa desenvolveu-se grandemente revelando uma visão multifacetada de Jesus. A atual fase da pesquisa redescobriu Jesus como um judeu, inserido na cultura e na religião judaicas de seu tempo. Essa redescoberta tornou-se ocasião propícia para um retorno às raízes judaicas do cristianismo, mas também abriu portas para um processo de judaização da fé cristã. Marca evidente dessa judaização é o fenômeno do Judaísmo Messiânico, hoje tão difundido no mundo inteiro. Ao enfatizar a judaicidade de Jesus, o judaísmo messiânico põe em xeque a maior parte das assertivas cristãs elaboradas ao longo de dois milênios de cristianismo, em especial a compreensão a respeito do modo de ser e de agir do messias.
\end{abstract}

Palavras-chave: Jesus histórico, pluralismo, identidade cristã, judaísmo messiânico.

\begin{abstract}
Modernity brought an impact on the Christian faith and these effects persist in Postmodernity. In the context of theology, the demand for a scientific answer for questions of modernity gave rise to research on the historical Jesus. There was an urgent need to know who is Jesus, how he lived and behaved, what his world or which words he pronounced in fact. That research was developed in distinct phases, revealing a plural understanding of Jesus. The current phase of the research rediscovered Jesus as a Jew, inserted in culture and religion Jewish of his time. This has become an occasion for a return to the Jewish roots of Christianity, but also initiated a process of Judaization of the Christian faith. Badge of Judaization is the phenomenon of Messianic Judaism, currently spread worldwide. To emphasize the Jewishness of Jesus, Messianic Jews calls into question most of the Christians assertions, which developed over two millennia of Christianity, particularly, the understanding about the way of being and acting of the Messiah.
\end{abstract}

Keywords: Historical Jesus, pluralism, Christian identity, Messianic Judaism.

\footnotetext{
Artigo recebido em 25 de junho de 2015 e aprovado em 22 de dezembro de 2015.

* Doutora em Catequética e mestre em Teologia Bíblica, professora do Curso de Teologia da PUC Minas e do ISTA. País de origem: Brasil. E mail: solangedocarmo@ig.com.br

** Doutora e mestre em Teologia Bíblica pela FAJE, professora da Faculdade Catolica de Fortaleza. País de origem: Brasil. E-mail: ailapinheiro@bol.com.br
} 


\section{Introdução}

No século I de nossa era difundiu-se amplamente uma diversidade de opiniões sobre Jesus. Tal diversidade gerou teologias distintas, como aparecem nos quatro Evangelhos canônicos (Mateus, Marcos, Lucas e João), cujas compreensões acerca do messias Jesus não são exatamente coincidentes, mas complementares. Tal diversidade, algumas vezes, desembocou em visões tão distorcidas da fé cristã, que as comunidades, herdeiras da fé apostólica, se viram obrigadas a rejeitá-las, recusando a leitura de seus escritos em suas liturgias e condenando tais visões como heréticas, perigosas para a fé autêntica professada pelos crentes.

Apesar dos perigos da diversidade, a fé cristã sempre conviveu com a pluralidade de opiniões, de visões teológicas, vendo nela uma riqueza. González Faus, em As dez heresias do Catolicismo atual - lembra-nos o duplo significado da palavra heresia (2012, p. 9). De um lado, o termo adquiriu, ao longo da história, um sentido negativo, de "uma parcialidade que absolutiza a si mesma de tal maneira que nega espaço a elementos imprescindíveis da fé cristã” (p. 10). Tal conceito cristalizou-se a ponto de fazer o sentido positivo inicial do termo praticamente desaparecer. A princípio, a palavra heresia significava apenas diversidade de opiniões; diversidade, aliás, louvada por Paulo em 1Cor 11,19. Afirma o apóstolo dos gentios que convém haver heresias, afinal, em sua compreensão, o termo hairesis significa parcialidade, em oposição a totalidade (p. 9), apontando para uma postura humilde dos cristãos, cuja riqueza se encontra na comunhão.

Visto que as comunidades cristãs do primeiro século não se configuravam de modo uniforme, convinha que uma pluralidade de compreensões teológicas se proliferasse em busca de complementação. Sendo assim, a diversidade de aproximações do messias era bem-vinda, e qualquer pretensão de compreensão monolítica sobre Jesus não se sustenta no Novo Testamento. Antes, se tal compreensão encontrou espaço na história, não foi no começo da Era Cristã, mas 
no cenário de decadência do império romano, o qual buscava um fator de unidade que assegurasse a própria existência por mais algum tempo. A fé cristã tornou-se o cimento que uniu os cacos do império, já com sinais de falência, mantendo o seu edifício erigido ainda por longos anos.

Após a queda do império romano, veio o fortalecimento da cristandade durante a Idade Média, na qual se estratificou uma compreensão monolítica sobre o messias. Com o advento da modernidade, tal concepção, promovida pelo império e reafirmada pela cristandade, conheceu seu ocaso. A modernidade e a pós-modernidade difundiram muitas concepções sobre Jesus, ventilaram novas compreensões, tentaram novas aproximações, observaram novas facetas do Mestre de Nazaré. Afinal, como disse Mendonça: “Jesus é um mistério fascinante, ainda em aberto" (2015, p. 301). Assim, os relatos do Novo Testamento foram revisitados com outros olhares e tornaram-se fonte de investigação criteriosa. A pesquisa bíblica se difundiu, ganhando estatuto de ciência, digna de credibilidade e passível de equívocos como qualquer outra, resultando na recuperação de uma pluralidade de compreensões acerca de Jesus, de sua vida, seus feitos, sua morte e sua ressureição. É sobre essa pluralidade de compreensões acerca de Jesus, esse mistério em aberto, que este artigo quer tratar, ou seja, quer mostrar as visões diversificadas sobre Jesus, que foram se sedimentando, através da pesquisa científica, a partir do advento da modernidade.

Ênfase será dada no fenômeno da judaização da fé cristã, constatada em algumas correntes messiânicas da atualidade, pois apesar de o judaísmo formativo, de vertente farisaica, ter rejeitado a messianidade de Jesus, muitos judeus aderiram ao Mestre da Galileia, sem, no entanto, se verem obrigados a abrir mão de suas tradições judaicas para assumir outra cultura. O mesmo aconteceu com os gentios, os quais não foram obrigados a judaizar-se, fruto do empenho de Paulo e do acordo firmado entre os apóstolos em Jerusalém (cf. 1Cor 7,18; At 15). Judeus e gentios vivenciavam a experiência da fé em Jesus Cristo, cada qual a partir de sua própria cultura. Esse fato histórico dos inícios do cristianismo, tão significativo para a fé cristã de todas as épocas, é desrespeitado em grande escala pelo que se 
denomina atualmente de judaísmo messiânico e por sua proposta de restauração de uma suposta igreja primitiva totalmente judaica e judaizante. Os fundamentos da cristologia e da eclesiologia, ou seja, a identidade de Jesus e do discipulado, firmada durante dois mil anos, são questionadas.

Dessa forma, o fenômeno do crescimento do judaísmo messiânico é um desafio para a teologia naquilo que é sua própria base.

\section{Alguns dados; algumas questões}

Conforme Stern, em 1988, aproximadamente mil pessoas se autodenominavam judeus messiânicos nos Estados Unidos. Em Israel, eram três mil congregados em vinte e cinco sinagogas messiânicas. Na Grã-Bretanha, cinco mil (1988, p. 179).

Nos últimos vintes anos, esses números aumentaram consideravelmente. $\mathrm{O}$ rápido desenvolvimento do judaísmo messiânico fez com que atualmente esse movimento tenha chegado até mesmo em alguns países da antiga União Soviética (Rússia, Ucrânia, Moldova, Belarus). Também já se estabeleceu amplamente na Europa Ocidental, embora não conte com grande número de membros; está na Inglaterra, na França, na Bélgica e nos Países Baixos. Na América Latina, encontra-se principalmente no Brasil, na Argentina e no México (JUSTER; HOCKEN, 2002, p. 9).

O visível crescimento do judaísmo messiânico leva a buscar os fatores que proporcionam seu surgimento e seu desenvolvimento. Somos impelidos a nos perguntar se o conceito de "messias" que sustenta tais grupos se identifica com a compreensão que os primeiros seguidores de Jesus tiveram de messias após a experiência pascal. 
Partindo da crise de fé - desencadeada pelo impacto da modernidade sobre a religião - e das diversas tentativas de resposta da cristologia, mostraremos brevemente o processo que desembocou numa ênfase exagerada da judaicidade de Jesus, culminando na sedução do judaísmo sobre o tempo presente, como consequência da atual crise da identidade cristã, especialmente no que se refere ao conceito de "messias".

\section{Desafios para a Teologia na modernidade e pós-modernidade}

Para a fé cristã, o Deus revelado permanece sempre escondido, ou seja, não se reduz ao mundo criado. Assim, as religiões cristãs se movimentam entre a palavra e o silêncio de Deus. Esse papel das religiões foi recebido com reservas pela modernidade. Racionalismo e empirismo modernos, com sua pretensão de conhecer a realidade inteira, viram a religião cristã como uma afronta aos princípios de cientificidade positiva, que se impunha naquele momento da história. Em resposta a essa suspeita, a Igreja recuou: temeu dialogar com a modernidade, enclausurando-se num idílio de cristandade.

Mas tal reação não parece condizente com a palavra de Deus que ressoa ainda hoje em nossos ouvidos: "Estai sempre preparados para [dar] resposta ante todo aquele que pedir razão da esperança que há em vós” (1Pd 3,15). Esta advertência da Escritura, bem diferente do que pode parecer a princípio, não convida a uma atitude apologética motivada pela reivindicação da posse da verdade absoluta, como foi praticada durante quase dois mil anos. Ao contrário, tal apelo nos conclama a uma postura lúcida de diálogo com o contexto no qual a comunidade cristã está inserida. Afinal, da verdade, ninguém se apropria, apenas se aproxima. Como afirma Villepelet, “o ser humano permanece em sua vizinhança ou na sua proximidade. Ele está mais ou menos na verdade. É preferível falar de uma proximidade da verdade que, a rigor, nos possui, mas que não podemos dominar" (2003, p. 110). 
Num desejo de aproximação da verdade, a teologia se ocupa em responder as questões de seu tempo, confrontando objeções, procurando alternativas no âmbito da linguagem e da experiência vivida por seus contemporâneos, expressando a fé cristã, tão antiga e, ao mesmo tempo, tão nova (cf. Mt 13,52). A pesquisa teológica empenha-se em fazer-se obediente à ordem daquele que inspirou as Escrituras: "Conduzi-vos com sabedoria para com os de fora, aproveitando bem a oportunidade (kairós - tempo). A vossa palavra seja sempre agradável, temperada com sal, para saberdes como deveis responder a cada um" (Cl 4,5-6), "fazendo-o, todavia, com mansidão e reverência, com boa consciência" (1Pd 3,16).

A expressão "os de fora" da Carta aos Colossenses caracteriza de modo apropriado o mundo moderno, pois este se configurou, principalmente, como secular, não sujeito à autoridade da Igreja e contraposto a ela. A modernidade viu nas afirmações teológicas uma espécie de obscurantismo, colocando a fé cristã sob a suspeita de impertinência. Os enunciados de fé foram entendidos como "lengalengas por longo tempo remoídas, velhas histórias desgastadas e estéreis" (VILLEPELET, 2000, p. 83), que não colaboram com o progresso humano, pois mantém a luz da razão na penumbra da religião.

Com o Iluminismo, uma ideia monocromática da realidade se implantou. O real passou a ser entendido apenas como aquilo que poderia ser explicado pela razão e pela verificação empírica. Os séculos XVIII e XIX foram de tal forma marcados pelo otimismo da razão que se cultivou o pensamento que os "mistérios" desse mundo poderiam ser explicados pela investigação científica, ou pelo menos elucidados por ela. O século XX se viu definido pelo desejo de ideias claras e distintas, observáveis, palpáveis, comprováveis. Essa reviravolta no modo de pensar provocou um impacto profundo na teologia e nos estudos bíblicos. Se o acesso à verdade era determinado pela análise científica, então, muitas afirmações dos textos bíblicos tornavam-se irrelevantes, se não absurdas, e pertenciam a uma era primitiva quando tudo era aceito como autêntico sem o crivo do tribunal da 
razão. A cosmovisão pré-moderna da coexistência de duas realidades - um reino invisível, espiritual, indissolúvel, unido ao mundo tangível - não podia mais ser pressuposto das pesquisas bíblicas influenciadas pelo empirismo. Era preciso submeter as Escrituras à investigação criteriosa dos instrumentos da razão crítica, sem falseá-las com os pressupostos da fé e da revelação. Era necessário fazer uma oposição, uma cisão, entre o sujeito do conhecimento (o crente) e o objeto estudado (a fé ou as Escrituras) (OLIVEIRA, 1989).

\section{Breve resumo da história}

Um resumo do processo de desenvolvimento da modernidade ajudará a entender o impacto provocado pela crítica moderna sobre a teologia.

Entre as principais causas históricas da modernidade, encontra-se o surgimento da imprensa e das universidades, que tornaram possível o acesso aos antigos textos dos sábios, os quais, até então, tinham sido propriedades da Igreja, por meio de seus ministros ordenados e de dedicados e estudiosos monges. Se, para os religiosos, havia a oportunidade de estudos aprofundados; para os leigos, havia apenas a pregação oral da Bíblia. Foi o Renascimento, nos séc. XV a XVI, que redescobriu o humanismo greco-latino de valorização do ser humano como determinante do conhecimento, abrindo portas para o acesso ao saber. Desde então, surgiu um esforço para arrancar das mãos da Igreja esse privilégio.

Outra causa importante nesse processo foi a ascensão da burguesia, que começou a se impor no quadro social. Possuidora de considerável riqueza adquirida através do comércio, a burguesia desejava se tornar culta e criar formas de vida menos rígidas, o que não seria possível enquanto a piedade religiosa continuasse a valorizar a vida pós-morte e os bens eternos. A valorização da vida além-morte ajudava a nutrir um desprezo pelos prazeres da vida terrena, inclusive

\footnotetext{
${ }^{1}$ Conforme Oliveira (1989), um dos traços fundamentais da modernidade é a "consciência de cisão", o surgimento do espírito moderno se caracteriza pelo aparecimento de um tipo de consciência diferenciada, cujo traço fundamental é "uma experiência de cisão entre o homem e Deus, entre filosofia e teologia, entre fé e ação temporal".
} 
pela posse de bens materiais e pelo conhecimento. Tudo era entendido como "vaidade das vaidades" (Ecl 1,2), dispêndio inútil de energias que deveriam ser investidas em tesouros espirituais, que renderiam juros a serem recolhidos na vida eterna.

O Renascimento foi, então, a primeira fase da sistematização do pensamento burguês. Trouxe à tona valores laicos como os prazeres da vida e atribuiu ao indivíduo uma honra não herdada, isto é, não derivada da nobreza, mas conquistada pela riqueza adquirida posteriormente através do comércio (MARTIN, 1984) ${ }^{2}$. Com isso, caíram os títulos e privilégios de algumas classes, inclusive do clero, que - na maioria das vezes -, em contraposição à maioria do povo, vivia de forma nababesca.

Pouco a pouco, um processo de dessacralização foi acontecendo. A Igreja passou a ser entendida como uma instituição entre tantas outras, sem os privilégios divinos antes a ela atribuídos. A secularização desmistificou as estruturas da Igreja e retirou-lhe o aspecto sobrenatural que garantia sua supremacia. Não demorou muito para que a religião caísse no descrédito, e a Igreja foi perdendo sua aura sagrada. Ideias anticlericais começaram a surgir, ganhando força no cenário da história. À religião ficaria relegado apenas um papel cultural. A Igreja foi entendida como detentora de um patrimônio cultural enorme, que deveria ser conservado, não em nome da fé, mas sim em nome da história humana. A religião passou a ser vista como uma criação humana, com objetivos ligados à vida terrena e não apenas à vida pós-morte. Entendeu-se que o ser humano criara Deus, e não o contrário. A existência humana passou a ser compreendida não somente como um estágio para a vida futura, mas como um modo de ser no mundo no qual a felicidade é possível e deve ser conquistada. A religião ficou relegada apenas a uma instância promotora de valores importantes para a conduta moral.

\footnotetext{
${ }^{2}$ Esta abordagem sobre o Renascimento e o processo de dessacralização segue, em linhas gerais, o estudo de Alfred von Martin (1984).
}

Horizonte, Belo Horizonte, v. 13, n. 40, p. 2194-2220, out./dez. 2015 - ISSN 2175-5841 
Paralelamente às teorias filosóficas que foram se desenvolvendo a partir do Renascimento, despontou um clima eufórico que desembocou numa confiança ilimitada no poder da ciência. A importância da ciência foi tal que ocasionou o chamado processo de reificação moderna, trazendo como consequência o ateísmo (ROUANET, 1993). Em suma, as palavras de Dostoievski começavam a fazer sentido. A modernidade ergueu "uma Torre de Babel que se eleva sem Deus, não para subir da terra ao céu, mas para fazer descer o céu até a terra” (DOSTOIÉVSKI, 2005, p. 33). Ou ainda o que afirma a Vulgata acerca da Torre de Tebes, onde todos se refugiaram fechando após si as portas e galgando ao seu topo (cf. Jz 9,51).

\section{Quem é Jesus? ${ }^{3}$ A busca do Jesus Histórico}

O processo histórico do pensamento moderno tornou inevitável um embate entre a "torre edificada" e o "velho edifício", entre a cosmovisão moderna e a cristã. No final do século XIX, o Modernismo (MARLÉ, 1960) ${ }^{4}$ penetrava nas instâncias eclesiais e um modernismo teológico intentava fazer reformas radicais na doutrina da Igreja, com o propósito de adaptá-la ao espírito da época.

As mudanças eram tais que parecia urgente adequar o cristianismo às necessidades intelectuais, morais e sociais dos tempos modernos. A adaptação querida pelos modernistas não era nada superficial: pretendia alcançar os fundamentos da fé cristã, "golpeando a velha carcaça da Igreja" até que "o velho edifício eclesiástico” desmoronasse, escreve Loisy (2014, p. 78).

O desejo dos modernistas não era gratuito. A encíclica Pascendi Dominici Gregis, do Papa Pio X, publicada em 8 de setembro de 1907, não perdoava as inovações advindas do processo de modernização. Seu escrito fazia uma síntese

\footnotetext{
${ }^{3}$ A pergunta cristológica que dá início à segunda parte do Evangelho de Marcos foi feita por Jesus, quando percebeu que seus discípulos não conseguiam situar-se a respeito da identidade do messias devido a várias concepções messiânicas da época (cf. Mc $8,27)$.

${ }^{4}$ O Modernismo foi uma maneira de ver e expressar o mundo com o objetivo de inserir a modernidade em todos os âmbitos da vida humana. Por modernismo teológico, compreende-se a tentativa de conciliar a fé cristã com alguns princípios da filosofia moderna. O modernismo teológico foi objeto de importantes atos do magistério do Papa Pio X (1903-1914), precisamente a encíclica Pascendi Dominici Gregis, que consagrou o uso do termo "modernismo" e determinou sua condenação (MARLÉ, 1960).
} 
das chamadas heresias fundadas sobre os sistemas filosóficos modernos, que segundo o papa - atacavam a Igreja, a divindade de Cristo, os dogmas, a disciplina, a autoridade e o pontificado (REARDON, 1970, p. 237-247). Começava a despontar na Igreja uma tomada de consciência acerca da descristianização da sociedade, e a comunidade cristã, em vez de ser o resto "erguido como bandeira para os povos" (cf. Is 11,10-11), reagia como um gueto - tão ameaçada se sentia!

Em contrapartida, de 1880 a 1900, movimentos de renovação surgiam na Igreja. Eles estavam em todos os âmbitos eclesiais e permeavam diversas áreas da fé católica: movimentos de renovação teológica, pastoral, bíblica, litúrgica, patrística, tomista e também do pensamento social (COMBY, 2001, p. 200-206). Dentro da própria Igreja, muitos cristãos já percebiam a necessidade de mudanças urgentes e, para isso, era preciso fazer um retorno às fontes da vida cristã e uma adaptação às mudanças dos tempos. Foi o papa Pio X quem assentou as bases dessa empreitada com sua famosa expressão "revertimini ad fontes".

Desse duplo movimento, de volta às fontes e de adaptação aos novos tempos, começou o processo para reconstituir uma imagem de Jesus que fizesse sentido para a mente científica moderna. Instigados pelo pensamento iluminista e imbuídos dos métodos modernos, os pesquisadores cristãos desejavam encontrar um Jesus que, de fato, fosse superior às apresentações eclesiásticas feitas durante séculos. Esse caminho científico foi visto como a chance de salvar a fé das "trevas do pré-criticismo", pela luz da razão pura, encontrando a figura mais preeminente de Jesus. Acreditava-se que, sob as diversas capas de tradições "lendárias" acerca de Jesus no Novo Testamento, havia dados que poderiam ser destrinchados para se construir o Jesus "real”, ou seja, um Jesus que fosse isento da mumificação de séculos de mitologia e da autoridade doutrinal. Tal pesquisa ancorava-se no desejo de libertar a imagem de Jesus de uma visão inferior, de uma imagem supersticiosa do Nazareno. 
Apesar dos protestos de alguns círculos de conservadores, os adeptos da Teologia Liberal (BROWN, 1985) 5 continuaram a impulsionar os estudos do Novo Testamento durante o século XIX. Acreditavam que o cristianismo pudesse se redescobrir, se fosse purificado através de fatos historicamente verificáveis sobre Jesus. Por detrás dessa atitude, residia subjacente a convicção de que a investigação histórico-científica era capaz de reconstruir a história a ponto de nos oferecer um Jesus real, sem a carcaça da fé católica, totalmente "de-doctrinised" (BROWN, 1985, p. 29-55).

\section{Bruta facta, a primeira fase 6}

O primeiro passo da pesquisa crítica sobre o Jesus da história ainda não estava articulado com a recusa sistemática da herança dogmática cristã. Era preciso bem mais que rejeitar a imagem antiga; urgente mesmo era - depois de retirados os excessos - encontrar a imagem original do Nazareno, ou seja, encontrar o Jesus histórico, em detrimento do Jesus da fé transmitido pela Igreja. Os primeiros esforços foram investidos para recuperar o "núcleo puro" do texto bíblico, especialmente, dos Evangelhos. Tal alvo foi alcançado, de certa forma, pelo movimento das "Vidas de Jesus" e pelo liberalismo teológico. Essa etapa da pesquisa ficou conhecida, posteriormente, como movimento historicista, situado na concepção geral da época de que somente a história seria capaz de estabelecer ou explicar a verdade. Os principais representantes dessa fase são Hermann Samuel Reimarus e David Friedrich Strauss (cf. THEISSEN; MERZ, 2004, p.2223).

Tendo sido despojado dos atributos divinos, o homem Jesus passou a ser visto como alguém carregado de valores humanistas, o que fazia dele um marco de referência para a consciência moderna. Jesus foi entendido como uma espécie de

\footnotetext{
${ }^{5}$ A expressão "liberalis theologia" remonta a Johann Salomo Semler (1725-1791). Semler pretendia, com o uso desta expressão, assinalar o uso do método histórico-crítico nas ciências bíblicas. O surgimento da Teologia Liberal situa-se no contexto da filosofia alemã e no interesse suscitado pelo estudo da Bíblia a partir dos pressupostos de Hegel e Schleiermacher (BROWN, 1985).

${ }^{6}$ Busca dos fatos puros sem as interpretações da fé.
} 
"gênio religioso" no qual as potencialidades do espírito humano atingiram o seu grau mais elevado e chegaram à apreensão de conhecimentos nunca antes alcançados (FUSCO, 1998, p. 27-30). Mais tarde, Albert Schweitzer (1875-1965) dirá que esse "Jesus objetivado" emergiu como uma projeção do idealismo utópico e humanitário do século XIX. Jesus teria sido recriado à imagem daqueles que buscavam reconstruí-lo (SCHWEITZER, 2001).

De 1830 a 1850, a escola de Tübingen deu novo impulso à pesquisa do Jesus histórico. Um de seus representantes mais célebres foi Ferdinand Christian Baur (1792-1860). Conforme sua teoria, os textos do Novo Testamento, mesmo passando pelo crivo da crítica moderna, não retratam a vida de Jesus; pois não são biografia do Nazareno e sim relatos que espelham os conflitos vividos pelos primeiros cristãos (HODGSON, 1966). Nesse tipo de postura, Tendenzkritik, a investigação gira em torno das tensões presentes no seio das primeiras comunidades cristãs. Assim, não fazia mais sentido o propósito da teologia liberal de encontrar os fatos puros da vida de Jesus; tal intento era impossível e todo esforço nesse sentido caíra no descrédito.

Na tentativa de descobrir o Jesus histórico, ganhou destaque o Evangelho de Marcos que - depois de longas pesquisas - passou a ser considerado como o mais primitivo e o que mais diretamente conduziria ao Jesus da história. Em 1901, Wilhelm Wrede (1859-1906) destronou as pretensões erigidas em torno do Segundo Evangelho, quando mostrou com sua obra que Mc não é nada mais que o produto da apologética eclesiástica que o elaborou. A teoria do segredo messiânico de Wrede mostrava o Evangelho de Marcos como uma construção literária e apontava para a distância entre o Jesus da história, que nunca teve consciência de ser o Messias, e o Cristo da fé, proclamado como Senhor Ressuscitado pela Igreja (WREDE, 1971).

Nessa etapa da pesquisa, a posição mais radical foi, certamente, a de Rudolf Bultmann (1884-1976), que fixou uma separação fundamental entre o Jesus da 
história e o Cristo da fé (BULTMANN, 1968). Quem foi Jesus não é possível dizer, insistia ele, e não se deve querer saber. Para o pesquisador protestante, somente o Cristo da fé é importante para o crente (BULTMANN, 1968)7. Para Bultmann, a pregação da Páscoa exige uma adesão, ou seja, o ser humano é chamado a responder existencialmente a Cristo presente aqui e agora, como Senhor crucificado e ressuscitado. Assim, não importa o Jesus da história, aliás, incognoscível (BULTMANN, 1958, p. 16-17) ${ }^{8}$; não é ele o objeto da fé. Para o teólogo protestante, é impossível descobrir, por trás dos Evangelhos, os bruta facta sobre Jesus. Interpretando Paulo, Bultmann não quis conhecer "o Cristo segundo a carne" (2Cor 5,16). Pouco importava se há continuidade ou rompimento entre o Jesus da história e o Cristo da fé. Crer no Cristo, presente nos Evangelhos, é a única atitude que conta. Para o pesquisador, a verdade de fé e a verdade histórica não andam juntas, exceto alguns fatos como, por exemplo, a crucifixão (BULTMANN, 1958, p. 16-17).

Em 1906, foi a vez de Albert Schweitzer, que publicou o livro "A questão do Jesus Histórico", com o intuito de avaliar as teorias anteriores sobre Jesus. Schweitzer criticou seus antecessores, afirmando que essas teorias não são fundadas em evidências científicas como se propunham e sim nas pressuposições filosóficas de cada pesquisador (SCHWEITZER, 2001). Em contraposição às teorias dos antecessores, a hipótese de Schweitzer procurava demonstrar que Jesus, após uma experiência singular no batismo, teria visto sua consciência messiânica aflorar. Muitos dos seus seguidores teriam acreditando que ele era o messias, mas sua morte na cruz os fez concluir que sua pretensa messianidade não passava de um engano. O movimento de Jesus teria terminado na cruz, se não fosse a fé pós-pascal. Para ele, a expansão do movimento de Jesus se deve ao anúncio de sua ressurreição. Assim, no pensamento de Schweitzer, a fundação da Igreja e o seu crescimento se devem ao kérygma apostólico, que dá credibilidade a

\footnotetext{
${ }^{7}$ Bultmann baseia-se na filosofia existencialista para a qual o ser humano foi lançado no mundo tendo como única certeza a morte e, por isso, sua existência seria sem sentido. Bultmann acredita que o Novo Testamento teria o sentido da existência humana, mais precisamente, a cruz salvadora de Cristo. Basta saber que Jesus existiu e morreu na cruz, isso seria tudo que se pode afirmar dele e nada mais requer a fé cristã. Quem tomar a decisão de viver e morrer para Cristo recebe a salvação. Para tal não é necessário o conhecimento do Jesus histórico.
} 
tudo que Jesus havia dito acerca de si mesmo (SCHWEITZER, 2001). A primeira etapa ou questão acerca do Jesus histórico encerra sua pesquisa nesse ponto. $\mathrm{O}$ que veio a seguir já caracteriza nova fase, pois se assenta sobre outros pressupostos.

\section{Ipsissima verba, a segunda fase ${ }^{9}$}

Depois que Bultmann acentuou a importância do kérygma proclamado pela Igreja primitiva, em contraposição com a busca do Jesus histórico, houve um período aproximadamente até 1950, sem grandes e valiosas produções em torno desse tema. Alguns estudiosos denominaram essa fase de "no quest". Além da teologia de Bultmann, a obra de Wrede havia desacreditado completamente o Evangelho de Marcos, entendido por muitos como aquele que melhor conduziria ao Jesus histórico.

Pesquisador importante nessa fase foi Joachim Jeremias (1900-1979). Jeremias propôs que, em vez de tentar reconstruir o Jesus histórico, a pesquisa deveria se voltar para a pregação do Nazareno (JEREMIAS, 1968). Por meio das ferramentas da crítica histórica, esse pesquisador procurou recuperar os ipsissima verba do Jesus histórico. Para ele, o anúncio feito por Jesus constituiria a única fonte indispensável da proclamação apostólica. Depois da suspeita a respeito do Evangelho de Marcos, Jeremias quis devolver uma confiança na "tradição de Jesus”. Nessa ocasião, a pesquisa passou a ter como objetivo alcançar as camadas da tradição palestina anterior ao Novo Testamento. Contudo, a tentativa de localizar o Jesus da tradição através de seus logia e parábolas mostrou-se problemática, pois não se chegou a um acordo sobre o que pode ser considerado como palavra autêntica de Jesus. O Nazareno não deixou nenhum registro puro do que disse ou fez como indivíduo histórico.

\footnotetext{
${ }^{8}$ Mesmo assim, se poderia conhecer algo de sua mensagem através de um processo de demitologização. (BULTMANN, 1958, p. 16-17).
}

${ }^{9}$ Busca das palavras ditas por Jesus sem nenhum acréscimo e/ou modificação feitos pela Igreja. 
Depois de Joaquim Jeremias, a perspectiva da pesquisa sobre Jesus conheceu uma virada radical. Os estudiosos que vieram a seguir não colocavam mais toda a tônica de seus trabalhos na história, mas sim na teologia querigmática, embora continuassem a usar o método histórico-crítico como ponto de partida. Tal teologia tinha um tom existencialista e era influenciada pelo pensamento dos filósofos Soren Kierkegaard (1813-1855) e Martin Heidegger (1889-1976) (BARTH, 1999).

A partir da influência desses pensadores, ganhou relevo uma tendência da pesquisa que fazia de Jesus uma espécie de existencialista do primeiro século de nossa era. A pregação de Jesus passou a ser vista como uma versão antiga da filosofia de Heidegger. A mensagem escatológica de Jesus sobre a vinda do Reino de Deus foi interpretada em termos existencialistas. A tensão entre o futuro e a necessidade de decidir em favor do Reino que se fez próximo era compatível com a tensão própria do existencialismo entre a história e a liberdade do ser humano (PERRIN, 1967).

E foi assim que as perspectivas e os métodos adotados pelos discípulos de Bultmann tomaram, em alguns aspectos, um rumo diferente da proposta desse exegeta. Um marco importante para firmar essa distinção foi a conferência pronunciada por Ernst Käsemann (1906-1998) sobre “o problema do Jesus histórico" (KÄSEMANN, 1972, p. 145-17) ${ }^{10}$. Käsemann tomou uma posição aberta contra Joachim Jeremias, acusando-o de tornar a fé cristã dependente da análise histórica. Jeremias quis oferecer uma imagem autêntica de Jesus assegurando possuir critérios e balizas dignos de confiança. Mas, de acordo com Käsemann, as pretensões de Jeremias configuraram-se como mais um ídolo fabricado pelas ideologias modernas. Além disso, seus esforços pareciam inúteis, dizia Käsemann, pois os resultados da ciência não são capazes de suscitar a fé. Para ele, o crente é

\footnotetext{
${ }^{10}$ A conferência, apresentada em 23 de outubro de 1953 para estudantes do pensamento de Bultmann, pode ser resumida em três teses principais: 1) sem uma conexão entre o Cristo da fé e o Jesus da história, o cristianismo se torna um mito a-histórico e o anúncio cristão, uma proclamação docetista. 2) Se a Igreja antiga teve tão pouco interesse pela história de Jesus, por que produziu os evangelhos, com aquele forte chamado para a história a cada passo? 3) Mesmo que os Evangelhos fossem apenas produtos da fé póspascal, pediriam uma credibilidade na identidade entre Jesus terrestre e o Senhor ressuscitado.
} 
posto diante da interpelação decisiva que lhe vem da pregação, não da pesquisa histórica.

Com respeito ao pensamento de Bultmann, Käsemann criticou, principalmente, a total desconexão entre história e fé e enfatizou que a pesquisa deveria procurar o enraizamento de Jesus na história, evitando assim, um tipo de docetismo, capaz de permitir aos estudiosos a construção de um Cristo conforme seus interesses.

Apesar de ressaltar que o cristão não funda sua fé sobre descobertas científicas, Käsemann insistiu numa reabilitação da história como instância crítica capaz de evitar o espiritualismo. Para ele, a fé cristã significa a configuração da vida do crente a uma pessoa, Jesus de Nazaré. Por isso, a fé cristã não deve desprezar a realidade concreta do Nazareno; a pesquisa histórica pode lhe ser útil como instância crítica da práxis hodierna. Käsemann insiste que não se busca o passado para justificar dogmas ou práticas, mas para evitar que o cristianismo se torne um mito, uma gnose ou uma ideologia (GISEL, 1983, p. 123).

Essa mudança de perspectiva suscitada por Käsemann fez surgir certo número de trabalhos entre 1960 e 1970. A tônica comum entre eles foi uma aproximação histórica mais modesta. Cresceu, desde então, a consciência de que é impossível reconstruir com precisão a existência de Jesus, exceto sua procedência da Galiléia e sua morte na cruz. Quanto a situar essas ou aquelas palavras no quadro de sua vida terrestre, isso seria definitivamente impossível (TROCME, 1971).

O primeiro a publicar um significativo estudo histórico sobre Jesus segundo essa nova perspectiva foi Günther Bornkamm (1905-1990), seguido pelo maior teórico dessa nova etapa da pesquisa, James McConkey Robinson (1924-). Enquanto isso, a posição cética de Bultmann encontrava cada vez menos aprovação, como transparece naobra intitulada "O Jesus da história e o Cristo do 
Kérygma”, publicada em 1960, contendo ensaios de Oscar Cullmann (1902-1999), Walter Grundmann (1906-1976), Leonhard Goppelt (1911-1973), Gerhard Delling (1905-1986) e outros (BRAATEN; HARRISVILLE, 1964)11.

Até esse estágio da pesquisa, apesar de se considerar a importância do Evento Cristo para a fé, Jesus ainda aparece como alguém que está desvinculado do contexto judaico de sua época. A ênfase na mensagem do Nazareno resultou num Jesus individualista, privatizado, divorciado de sua situação social (BORG, 1994, p. 6). Essa posição forçou uma passagem para uma nova etapa da pesquisa, a chamada terceira questão.

\section{Revertimini ad fontes, a terceira fase ${ }^{12}$}

Como foi mostrado anteriormente, os discípulos de Bultmann haviam começado uma segunda etapa da pesquisa. Rompendo com a posição de seu mestre, afirmaram a possibilidade de conhecer a mensagem de Jesus e destacaram sua centralidade para a vida e para a teologia cristã. Mas, confiaram demasiadamente no que acreditavam ser os autênticos logia de Jesus. Mesmo fazendo uso de ferramentas como a crítica das formas, a segunda etapa tinha se agarrado a uma extrema visão apocalíptica. E, de certo modo, compreendeu a Escritura de forma semelhante a Wilhelm Wrede, para o qual o conteúdo do Evangelho de Marcos equivaleria mais a um produto da Igreja Primitiva, sendo inútil a tentativa de estabelecer qualquer tipo de verdade histórica nesse campo (WREDE, 1971).

Depois disso, desde 1980 até hoje, emergiu uma terceira etapa da pesquisa sobre o Jesus histórico (NEILL, 1988, p. 379-403), que mostra uma importante distinção da anterior. Essa etapa da pesquisa entende que um enfoque puramente voltado para a mensagem de Jesus o torna desencarnado e distorce sua real imagem. Assim, reconhece que os Evangelhos relatam o ensino de Jesus como

\footnotetext{
${ }^{11}$ Cf. a tradução para o inglês: BRAATEN; HARRISVILLE, 1964.
} 
parte integrante da estratégia de sua missão, na qual está diretamente implicado o mundo social e político da época em que viveu (BORG, 1994, p.12).

Esse tipo de reflexão tronou-se possível graças a alguns fatores históricos. Um deles foi a Teologia Latino-americana da Libertação (HARRINGTON, 1988, p. 77-85), que teve um importante papel para a recente sensibilidade dos estudiosos em relação a algumas dimensões do contexto do Novo Testamento, antes esquecidas. O método da Teologia da Libertação recebeu apoio decisivo de alguns biblistas europeus e norte-americanos que passaram a utilizar também a contribuição da sociologia, da antropologia e de outras ciências em suas pesquisas bíblicas e teológicas. A questão sobre o Jesus histórico tornou-se interdisciplinar, recebendo um impulso adicional que vinha das novas descobertas arqueológicas que desvendam o contexto mundial do século I da era cristã (BORG, 1994, p. 10. 19).

Um diferencial surge na terceira questão em relação às anteriores. Se nas duas primeiras os pesquisadores acreditavam que os resultados científicos levavam à profissão de fé, na terceira etapa, parte-se da fé para uma investigação científica. A procura do Jesus histórico, nessa fase, ocupa-se mais em encontrar os critérios de ponderação da práxis cristã que as bases científicas que levem à fé (THEISSEN; MERZ, 2004). Para aumentar ainda mais a credibilidade de seus trabalhos, pesquisadores da terceira questão extrapolam os limites do Cânon do Novo Testamento, analisando também documentos extrabíblicos surgidos ao redor do primeiro século da era cristã.

Enquanto pesquisadores da terceira etapa se debruçavam sobre sua pesquisa dentro do âmbito da fé cristã, paralelamente desenvolvia-se o pluralismo religioso e cultural na sociedade secular. Várias Faculdades interessaram-se pela cultura religiosa e muitos estudiosos do Novo Testamento passaram a ensinar fora do ambiente eclesial, deparando-se com novas questões formuladas por alunos

\footnotetext{
${ }^{12}$ Volta às fontes que se caracteriza pela pesquisa sobre o ambiente histórico-cultural em torno ao século I EC.
} 
seculares, que tinham visões diversificadas sobre as experiências religiosas da humanidade (BORG, 1994, p. 6).

Como qualquer movimento genuinamente intelectual, a terceira etapa da pesquisa sobre o Jesus histórico está longe de ser monolítica. Incorpora um grande número de opiniões, mas a tendência dominante parece ser a de reconstruir um Jesus histórico como um mestre de sabedoria não-apocalíptico (PATTERSON, 1995, p. 31-42), bem o contrário do que pensavam alguns como Johannes Weiss (1863-1914) naquele que foi o paradigma dominante para se compreender Jesus durante a maior parte do século XX.

O recente desenvolvimento da pesquisa histórico-crítica comprometeu a hipótese de Schweitzer (PATTERSON, 1995, p. 35-41). O Jesus apocalíptico foi minado pelos recentes estudos sobre o Evangelho de Tomé e a Fonte Q, os quais identificam a mais antiga tradição sobre Jesus com ditos aforísticos sapienciais e não com a corrente apocalíptica, como se pensou antes. Muitos estudiosos conjeturam que há três camadas na fonte $Q$, representando diferentes estágios no desenvolvimento da comunidade cristã palestina. A primeira camada seria a mais próxima do Jesus histórico e consistiria de ensinamentos sapienciais. A falta de logia apocalípticas nessa camada levou os estudiosos a desafiarem a visão apocalíptica que se tinha de Jesus (KLOPPENBORG, 1987).

A imagem de um Jesus apocalíptico foi progressivamente mudada pelos pesquisadores pós-bultmannianos, tais como Philipp Vielhauer (1914-1977), Hans Conzelmann (1915-1989) e Ernst Käsemann. Seus estudos, geralmente, enfatizaram o presente, o aqui e o agora da natureza do Reino de Deus na proclamação de Jesus (KLOPPENBORG, 1987). Além do mais, os estudos de Amos Niven Wilder (1895-1993) sobre as parábolas de Jesus também contribuíram para uma nova compreensão da atuação de Deus que irrompe no presente, em vez de num momento futuro indeterminável (WILDER, p. 1939). 
Atualmente, as novas pesquisas - auxiliadas por critérios sociopolíticos, antropológicos e tipológicos de reconstrução histórica e não somente ancoradas na crítica das formas - levam a enfatizar Jesus enquanto judeu e insistem na necessidade de compreendê-lo no contexto do judaísmo do primeiro século. Desde então, a atenção da pesquisa tem se voltado para o mundo sociocultural da Palestina do século I. Compreendendo-se melhor o mundo judaico no qual Jesus estava totalmente imerso, entende-se que se abrem novas possibilidades para compreender melhor o Mestre de Nazaré.

\section{De Jesus - o judeu - à judaicidade das Igrejas $^{13}$}

Com a pesquisa da terceira etapa, observa-se claramente uma revalorização do mundo de Jesus, o judaísmo. Ganha primazia na leitura dos Evangelhos a cultura, a religião, o mundo social do judaísmo no qual Jesus estava imerso. Essa ênfase que a terceira questão deu à judaicidade de Jesus, unida ao impacto da crítica moderna à religião, parece estar provocando um efeito pendular. Se antes havia uma disjunção entre Jesus e o judaísmo, nota-se agora uma separação radical entre Jesus e a Igreja, um esforço enorme para mostrar que a comunidade cristã é bem posterior aos primeiros séculos da era cristã e em nada está referida às intenções do Jesus histórico quando escolheu seus seguidores. É nesse contexto que ganha relevância o judaísmo messiânico.

Os grupos de judeus messiânicos não estão de acordo entre si sobre a maioria dos conteúdos da doutrina cristã que foi sendo elaborada ao longo desses mais de dois mil anos de cristianismo. Contudo, a maioria concorda que o termo “cristão" não se refere aos primeiros seguidores de Jesus e serviria apenas para designar os gentios que aderiram às comunidades no final do primeiro século. Conforme os judeus messiânicos, enquanto o Evangelho foi proclamado apenas aos judeus (At 11,19), os seguidores de Jesus não foram chamados de cristãos; isso 
só aconteceu quando o anúncio foi dirigido aos gentios (At 11,20.26). Inclusive argumentam que os discípulos e apóstolos e outros judeus que aderiram a Jesus através do anúncio apostólico reuniam-se em sinagogas, conforme testemunham alguns textos do Novo Testamento como $\mathrm{Tg}$ 2,2 e $\mathrm{Hb}$ 10,25. Eram sinagogas as primeiras comunidades de seguidores, defende atualmente o Judaísmo Messiânico estrito. Mas quem são os judeus messiânicos?

No sentido exato, o Judaísmo Messiânico é mais um entre os diversos ramos do judaísmo atual14. É formado por judeus que observam a Torah e aceitam Jesus como Filho de Deus; acreditam na expiação dos pecados pelo sacrifício perpétuo realizado por Jesus através de sua vida-morte-ressurreição e praticam o batismo por imersão como Rito de Iniciação. Insistem na necessidade de se congregar em sinagogas e não em igrejas pertencentes às diversas denominações cristãs atuais, embora geralmente aceitem em suas sinagogas membros gentios sem exigência de circuncisão. Fundamentam essa posição doutrinária em 1Cor 7,18.20: "Foi alguém chamado, estando circunciso? Não desfaça a circuncisão. Foi alguém chamado, estando incircunciso? Não se faça circuncidar. Cada um permaneça no estado em que foi chamado". Assim, entendem que os judeus crentes em Jesus se congregam numa qehilah (termo hebraico equivalente ao grego "sinagoga”) e não numa Igreja e se denominam judeus messiânicos e não cristãos.

Mas, além de atualmente haver um grande número de judeus messiânicos, outro fator deve chamar nossa atenção. O destaque dado à judaicidade de Jesus, pela terceira questão do Jesus histórico, unido à supervalorização de culturas antigas e a um renovado conservadorismo, enquanto efeitos pendulares de nossa época em reação ao período histórico precedente, trouxe como consequência um fenômeno cunhado de "superjudeu” (KOLATCH, 1985).

\footnotetext{
${ }^{13}$ Este tópico segue, em linhas gerais, as recentes publicações sobre o Judaísmo Messiânico nas seguintes obras: DORFF, 1996; FISCHER, 2000; FIELDSEND, 1993; ALEXANDER, 1994; FRIEDMAN, 2001.

${ }^{14}$ Os demais ramos são: o Ortodoxo, o Conservador (Masorti), o Reformista (conhecido também como Progressista ou Liberal), o Reconstrucionista, Neo-hassídico (Caraíta), o Humanista (não exige crença em Deus) e o Ultra-liberal.
} 
Trata-se de evangélicos decepcionados com diversas denominações pelas quais passaram e que se identificam como judeus, mesmo não tendo nenhuma ascendência judaica. São, geralmente, caricaturas de judeus ortodoxos, pois se utilizam de símbolos, indumentárias e práticas judaicas desconexas, além de um vocabulário hebraico bastante difundido na internet ${ }^{15}$.

Praticam a circuncisão embora muitas vezes não a distingam de uma postectomia totalmente secular. Observam rigorosamente o Sábado, as Festas Judaicas e as regras alimentares. Além disso, esperam a reconstrução do Templo de Jerusalém e a volta dos sacrifícios de animais. A ordenação de seus rabinos não é reconhecida por nenhum ramo do judaísmo, pois, além de não terem a formação necessária, também não participaram do ritual adequado.

Esse suposto judaísmo messiânico, como se identificam esses movimentos, geralmente veio de grupos pentecostais tanto da Igreja Católica quanto de outras denominações cristãs. Suas reuniões sabáticas são fortemente marcadas pela manifestação dos carismas do Espírito Santo. Autodenominam-se de judeus messiânicos ortodoxos e dizem acreditar em Yeshua' (Jesus) como messias, mas não como Filho de Deus, como afirma o cristianismo tradicional. Fundamentam sua suposta judaicidade no argumento de que, sendo Jesus judeu, cada membro do seu Corpo, a saber, o grupo religioso, também é judeu.

Para o Judaísmo Messiânico estrito ${ }^{16}$, os superjudeus são falsos judeus que põem em perigo a judaicidade do movimento de restauração das raízes judaicas da Igreja e do desenvolvimento da terceira etapa da pesquisa sobre o Jesus histórico.

A proliferação dos superjudeus se deu pela Europa, Estados Unidos e chegou ao Brasil, constituindo-se um desafio para a fé cristológica, exigindo uma

\footnotetext{
${ }^{15}$ Sobre essa judiação externa, a mídia não se cansou de divulgar a inauguração do templo de Salomão da Igreja universal do Reino de Deus, cujo pastor, Edir Macedo, se apresentou com indumentária pretensamente judaica, mas extremamente extravagante, em tal evento.

${ }^{16}$ O termo "estrito" refere-se ao judaísmo messiânico cujos membros são judeus. O termo "amplo" refere-se a qualquer grupo cujos membros se dizem judeus.
} 
fundamentação teológica do que significa crer em Jesus, o Messias.

\section{Conclusão}

Delineamos as diversas etapas da pesquisa bíblica até chegar à etapa atual da pesquisa a respeito do Jesus histórico, bem como a relevância desse tema para a época hodierna. Sobretudo, procuramos demonstrar o impacto da modernidade sobre a fé cristológica e as diversas tentativas de respostas da exegese bíblica às questões levantadas pela crítica filosófica moderna.

Apresentamos, em linhas gerais, as três fases principais da pesquisa sobre o Jesus histórico. A primeira enfatiza mais os eventos e tem como objetivo descobrir os atos concretos realizados por Jesus. A segunda realça o valor das palavras e procura certificar-se sobre os verdadeiros logia de Jesus. A fase atual se caracteriza por um retorno ao contexto geral da Palestina, desde o período intertestamentário até o final do primeiro século da era cristã.

Vimos que a crítica moderna à Igreja persiste na pós-modernidade e que as pretensões de responder-lhe podem tornar-se infrutíferas se o "Evento Cristo" (Jesus histórico e seus primeiros seguidores) for compreendido de forma desvinculada de seu tempo e de sua situação cultural, religiosa e histórica. Uma resposta adequada e sincera necessita levar em conta tanto as rupturas quanto as dependências da hermenêutica cristã em relação à literatura judaica.

Atualmente, a terceira fase procura as tradições de Jesus porque o ser humano é tradição. Os cristãos não crêem num mito, nem em proposições e nem em resultados científicos. A profissão de fé cristã é fundada numa pessoa concreta, histórica. Quem é essa pessoa, então? A partir do judaísmo, mundo que Jesus assumiu e no qual viveu, aumentam as chances de saber quem é Jesus. 
Da procura pelas raízes judaicas de Jesus, ganha força o judaísmo messiânico. A partir dele, uma nova vertente, denominada superjudeus, que afirma acreditar na messianidade de Jesus. Mas qual o significado do termo messias? No período histórico do intertestamento e por volta do primeiro século da era comum, esse termo não parece ter sido tão claro e seu significado não foi definido com unanimidade.

O retorno ao ambiente histórico no qual surgiu a fé em Jesus como messias se torna imprescindível para se compreender o específico cristão quando se afirma que Jesus é o messias, o Cristo.

As questões acerca de Jesus, o messias, continuam e as demandas nesse campo permanecem. A espera pelo messias foi algo difundido ou isolado no judaísmo palestino anterior ao século I de nossa era? O que era mais importante, um messias ou um mundo (era) de paz? A partir de qual fator se pode encontrar o gérmen das expectativas por um redentor político-religioso? Um vasto campo da pesquisa continua aberto esperando novos ensaios...

\section{REFERÊNCIAS}

ALEXANDER, Linda. The unpromised land: the struggle of Messianic Jews. Baltimore: Lederer Messianic Publications, 1994.

BARTH, Karl. Carta aos Romanos. São Paulo: Novo Século, 1999.

BORG, Marcus. Jesus in Contemporary Scholarship. Pennsylvania: Trinity Press International, 1994.

BORNKAMM, Günther. Gesù di Nazaret. Torino: Claudiana, 1977.

BRAATEN, Carl E; HARRISVILLE, Roy A. The historical Jesus and the kerygmatic Christ: essays on the new quest of the historical Jesus. New York: Abingdon Press, 1964.

BROWN, Colin. Jesus in European Protestant Thought. Grand Rapids: Baker Books, 1985 . 
BULTMANN, Rudolf. Jesus and the Word. New York: Scribner, 1958.

BULTMANN, Rudolf. Jésus. Paris: Seuil, 1968.

COMBY, Jean. Para ler a história da Igreja II: do século XV ao século XX. São Paulo: Loyola, 2001.

CONGAR, Yves. Chrétiens en dialogue: contributions catholiques à l'oecuménisme. Paris: Éditions du Cerf, 1964.

DORFF, Elliot $\mathrm{N}$. This is my beloved, this is my friend: a rabbinic letter on intimate relations. New York: Rabbinical Assembly, 1996.

DOSTOIÉVSKI, Fiodor M. Os Irmãos Karamazovi. São Paulo: Martin Claret, 2005.

FIELDSEND, John. Messianic Jews: challenging church and synagogue. Tunbridge Wells: MARC, 1993.

FISCHER, Raymond Robert. The children of God: Messianic Jews and gentile Christians nourished by common Jewish roots. Tiberias (Israel): Olim Publications, 2000.

FRIEDMAN, David. They loved the Torah: what Yeshua's first followers really thought about the Law. Baltimore: Lederer Books, 2001.

FUSCO, Vittorio. La quête du Jésus historique. In: MARGUERAT, Daniel et. al. (ed.). Jésus de Nazareth: Nouvelles approches d'une énigme. Genève: Labor et Fides, 1998, p. 25-57.

GISEL, Pierre. Vérité et Histoire: la théologie dans la modernité. Paris: Beauchesne, 1983.

GONZÁlEZ FAUS. José I. As dez heresias do catolicismo atual. Petrópolis: Vozes, 2015 .

HARRINGTON, Daniel. Second Testament Exegesis and the Social Sciences: a bibliography, Biblical Theology Bulletin, New Jersey, v. 18, n.2, p. 77-85, 1988.

HODGSON, Peter C. The formation of historical theology: a study of Ferdinand Christian Baur. New York: Harper \& Row, 1966.

JEREMIAS, Joachim. Le problème historique de Jésus-Christ. Paris: Editions de l'Epi, 1968.

JUSTER, Daniel; HOCKEN, Peter. El Movimiento Judío Mesiánico: una Introducción, Jerusalén: Toward Jerusalem Counsil II Publications, 2002.

KÄSEMANN, Ernst. Le problème du Jésus historique. In : KÄSEMANN, Ernst. Essais exégétiques. Neuchâtel: Delachaux et Niestlé, 1972, p. 145-173. 
KLOPPENBORG, John S. The Formation of Q: Trajectories in Ancient Wisdom Collections. Philadelphia: Fortress Press, 1987.

KOLATCH, Alfred J. The second Jewish book of why. Nova York: J. David Publishers, 1985 .

LOISY, Alfred. Vocation. In: VIDLER, Alec. The Modernist Movement in Roman Church: Its origins and outcome. Cambridge: Cambridge University Press, 2014, p. 6980 .

MARLÉ, René. Au coeur de la crise moderniste: Le dossier inédit d'une controverse. Paris: Aubier, 1960.

MARTIN, Alfred von. Sociología del Renascimiento. Mexico: Fondo de Cultura Económica, 1946.

MENDONÇA, José Tolentino. A leitura infinita: a bíblia e sua interpretação. São Paulo: Paulinas, 2015.

NEILL, Stephen. The Interpretation of the New Testament: 1861-1986. Oxford/New York: Oxford University Press, 1988.

OLIVEIRA, Manfredo A. de. A Filosofia na Crise da Modernidade. São Paulo: Loyola, 1989.

PATTERSON, Stephen J. The End of Apocalypse: Rethinking the Eschatological Jesus, Theology Today, USA, n. 52, 1995, p. 31-42.

PERRIN, Norman. Rediscovering the Teaching of Jesus. New York: Harper and Row, 1967.

REARDON, Bernard M. G. Roman Catholic modernism. London: A. \& C. Black, 1970. ROBINSON, James McConkey. A new quest of the historical Jesus and other essays. Philadelphia: Fortress Press, 1983.

ROUANET, Sérgio P. Mal-Estar da Modernidade. São Paulo: Companhia das Letras, 1993.

SCHWEITZER, Albert. The quest of the historical Jesus. Minneapolis: Fortress Press, 2001.

SEVCENKO, Nicolau. O Renascimento. São Paulo: Atual \& Campinas/Unicamp, 1984. STERN, David. Messianic Jewish Manifesto. Jerusalem: Jewish New Testament Publications, 1988. 
THEISSEN, Gerd; MERZ, Annette. O Jesus Histórico: um Manual, São Paulo: Loyola, 2004 .

TROCME, Etienne. Jésus de Nazareth vu par les témoins de sa vie. Neuchâtel: Delachaux et Niestlé, 1971.

VILLEPELET, Denis. Catéchèse et crise de la transmission. In: VILLEPELET, Denis; GAGEY, Henri Jérôme (org.). Sur la proposition de la foi. Paris: L’Atelier, 2000. p. 7792.

VILLEPELET, Denis. L’avenir de la catéchèse. Paris: L’atelier/Ouvrières, 2003.

WILDER, Amos N. Eschatology and Ethics in the Teaching of Jesus. New York/London: Harper \& brothers, 1939.

WREDE, Wilhelm. The Messianic secret. Philadelphia: J. Clarke, 1971. 